Review Article

\title{
Chronic Subdural Hematoma in the Aged, Trauma or Degeneration?
}

\author{
Kyeong-Seok Lee, M.D. \\ Department of Neurosurgery, Soonchunhyang University Cheonan Hospital, Cheonan, Korea
}

\begin{abstract}
Chronic subdural hematomas (CSHs) are generally regarded to be a traumatic lesion. It was regarded as a stroke in 17th century, an inflammatory disease in 19th century. From 20th century, it became a traumatic lesion. CSH frequently occur after a trauma, however, it cannot occur when there is no enough subdural space even after a severe head injury. CSH may occur without trauma, when there is sufficient subdural space. The author tried to investigate trends in the causation of CSH. By a review of literature, the author suggested a different view on the causation of CSH. CSH usually originated from either a subdural hygroma or an acute subdural hematoma. Development of CSH starts from the separation of the dural border cell (DBC) layer, which induces proliferation of DBCs with production of neomembrane. Capillaries will follow along the neomembrane. Hemorrhage would occur into the subdural fluid either by tearing of bridge veins or repeated microhemorrhage from the neomembrane. That is the mechanism of hematoma enlargement. Trauma or bleeding tendency may precipitate development of CSH, however, it cannot lead CSH, if there is no sufficient subdural space. The key determinant for development of CSH is a sufficient subdural space, in other words, brain atrophy. The most common and universal cause of brain atrophy is the aging. Modifying Virchow's description, CSH is sometimes traumatic, but most often caused by degeneration of the brain. Now, it is reasonable that degeneration of brain might play pivotal role in development of CSH in the aged persons.
\end{abstract}

Key Words : Hematoma subdural chronic $\cdot$ Causality $\cdot$ Classification $\cdot$ Aging $\cdot$ Intracranial pressure $\cdot$ Craniocerebral trauma.

\section{INTRODUCTION}

Chronic subdural hematomas (CSHs) are generally regarded to be consequences of head trauma ${ }^{14,51)}$. The most commonly accepted pathophysiological explanation of $\mathrm{CSH}$ is that mild head trauma leads to tearing of bridging veins with subsequent bleeding, thus creating the hematoma ${ }^{7}$. However, a history of trauma is absent in about $30-50 \%$ of the cases, especially after the age of 65 years ${ }^{1,12,19,52)}$. Besides trauma, there were numerous risk factors such as alcohol abuse, seizures, cerebrospinal fluid shunts, and coagulopathies including therapeutic anticoagulant ${ }^{14,51)}$.

In 17th century, CSH was a stroke. It became an inflammation in 19th century and finally a traumatic lesion in 20th century. Trauma is the most commonly alluded as a cause, however, it cannot occur when there is no enough subdural space even after a severe head injury. If there is sufficient subdural space, CSH may occur without trauma such as intracranial hypotension. Causation of $\mathrm{CSH}$ is an important issue in the accident insurance. The author tried to investigate trends in the causality of CSH.

\section{MATERIALS AND METHODS}

A computerized search of the National Library of Medicine (PubMed) database of the up-to-date literature (published from 2010 to 2014) was undertaken. The medical subject headings "chronic subdural hematoma" combined with "causality" yielded 197 citations (excluded non-English language and non-human citations). The abstracts of relevant citations were reviewed and 41 articles were selected. The selected papers have been categorized into one of five categories by the causalities proposed by the authors (Table 1). By a review of literature, the author suggested a different view on the causation of $\mathrm{CSH}$.

\section{RESULTS}

As the cause of CSH, sufficient subdural space was alluded in 19 papers, coagulopathy in 13 papers, and trauma in 8 papers, including the combined categories. Sufficient subdural space included arachnoid cyst, cerebrospinal fluid leak, lumbar drainage, spinal anesthesia, intracranial hypotension, hydrocephalus,

- Received : July 17, 2015 • Revised : October 22, 2015 • Accepted : December 3, 2015

- Address for reprints : Kyeong-Seok Lee, M.D.

Department of Neurosurgery, Soonchunhyang University Cheonan Hospital, 31 Soonchunhyang 6-gil, Cheonan 31151, Korea

Tel : +82-41-570-3652, Fax : +82-41-572-9297, E-mail : ksleens@sch.ac.kr

- This is an Open Access article distributed under the terms of the Creative Commons Attribution Non-Commercial License (http://creativecommons.org/licenses/by-nc/3.0) which permits unrestricted non-commercial use, distribution, and reproduction in any medium, provided the original work is properly cited. 
Table 1. Causality of chronic subdural hematomas in selected papers (2010-2014)

\begin{tabular}{|c|c|}
\hline Category & Authors (year) \\
\hline Coagulopathy & $\begin{array}{l}\text { Kawano et al. }(2013)^{26)} \text {, Sakai et al. }(2011)^{46)} \text {, Vuk et al. }(2010)^{61)} \text {, De Bonis et al. }(2013)^{14)} \text {, Ledić et al. }(2014)^{32)} \text {, } \\
\text { Wang et al. }(2013)^{62)} \text {, Senturk et al. }(2010)^{51)} \text {, Bosche et al. }(2012)^{10)} \text {, Luongo et al. }(2012)^{37)}\end{array}$ \\
\hline Sufficient SS & $\begin{array}{l}\text { Zeng et al. }(2011)^{65)} \text {, Kertmen et al. }(2012)^{27)} \text {, Takayasu et al. }(2012)^{55)} \text {, Lohani et al. }(2013)^{36)} \text {, Kwak et al. }(2013)^{31)} \text {, } \\
\text { Edmondson et al. }(2014)^{16)} \text {, Yang et al. }(2012)^{63)} \text {, Beck et al. }(2014)^{7)} \text {, Yoshida et al. }(2014)^{64)} \text {, Tekin et al. }(2012)^{58)} \text {, } \\
\left.\text { Ferrante et al. }(2010)^{18)} \text {, Schievink }(2013)^{47}\right) \text { Tan and Liew }(2013)^{56)} \text {, Inamasu et al. }(2013)^{25)} \text {, Amorim et al. }(2010)^{2)} \text {, } \\
\text { Ohno et al. }(2013)^{41)} \text {, Tseng et al. }(2014)^{60)}\end{array}$ \\
\hline Trauma & $\begin{array}{l}\text { Pirayesh Islamian et al. }(2014)^{43)} \text {, Tanaka and Ohno }(2013)^{57)} \text {, Borger et al. }(2012)^{9)} \text {, Sousa et al. }(2013)^{53)} \text {, } \\
\text { De Carvalho et al. }(2013)^{15)}\end{array}$ \\
\hline Combined & Reichman et al. $(2012)^{45)}$, Aspegren et al. $(2013)^{4)}$, Hagihara et al. $(2010)^{23)}$, Schievink et ak. $(2010)^{48)}$ \\
\hline Others & $\begin{array}{l}\text { Kuan-Yin et al. }(2013)^{29)} \text {, Prasad et al. }(2013)^{44)} \text {, Barrios et al. }(2014)^{6)} \text {, Goto et al. }(2013)^{22)} \text {, Gabaeff }(2013)^{21)} \text {, } \\
\text { Eljebbouri et al. }(2013)^{17)}\end{array}$ \\
\hline
\end{tabular}

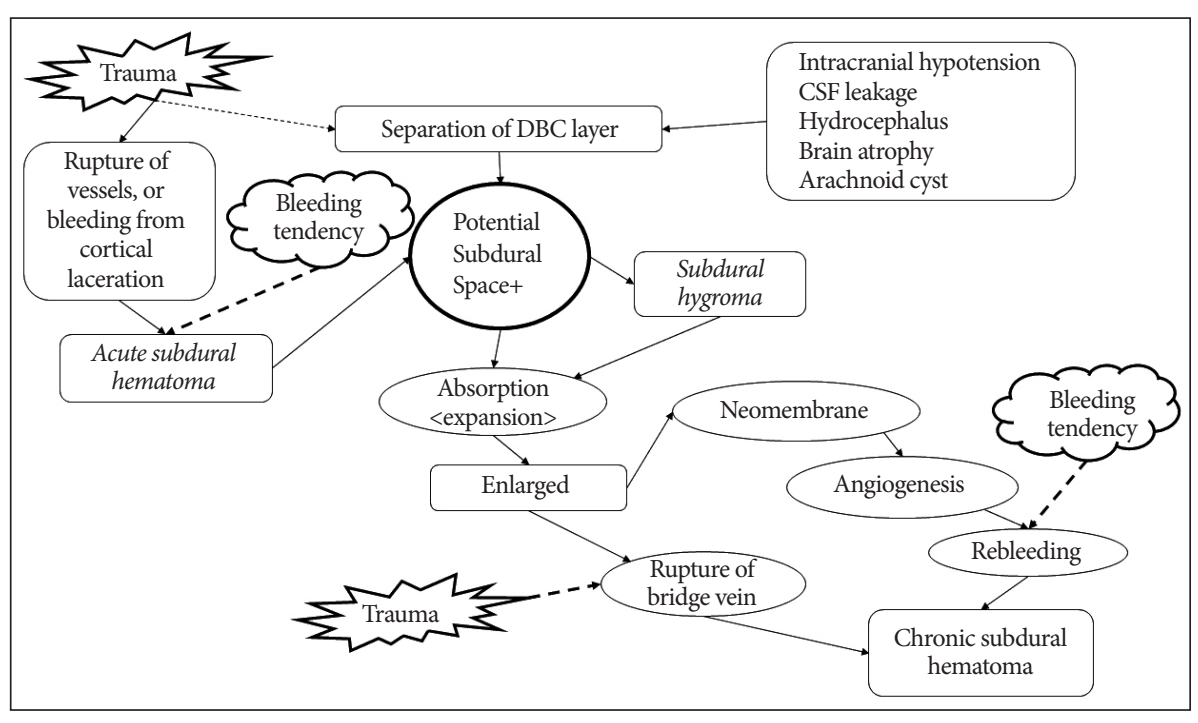

Fig. 1. Schematic representation of the web of causation model for causation of chronic subdural hematoma. Development of CSH starts from the separation of the dural border cell (DBC) layer. Trauma or bleeding tendency may precipitate hematoma formation, however, it cannot produce chronic subdural hematoma, when there is no potential subdural space. The real lines mean direct causal relationships, while the dotted lines represent precipitations. Adopted from Lee KS et al. ${ }^{34}$, with permission from $\mathrm{Br} \mathrm{J}$ Neurosurg. cerebral atrophy, and the old age. Coagulopathy included factor $\mathrm{X}$ deficiency, factor XIII deficiency, von Willebrand's disease, afibrinogenemia, anticoagulant therapy, and end stage renal disease. Trauma included head-banging, dancing, and any tears in the arachnoid membrane following contusion of the brain or slight bleeding from a bridging vein. Combined category included trauma with coagulopathy or sufficient subdural space with coagulopathy. Others included dural metastasis, lymphoma, infection, antiviral therapy, and birth related complications.

\section{DISCUSSION}

Sufficient subdural space was the most commonly alluded as the cause of $\mathrm{CSH}$. The number of papers did not have a value by itself, since papers did not have equal frequency or importance. However, it may represent relative importance or apportionment of certain factors. Recent papers may not represent the whole aspects of the causation. They may have a tendency to publish atypical cases. However, we can explore this curious lesion using the more updated knowledge.

Traditional model of causation, so-called the classic epidemi- ologic triangle of host, agent, and environment was not suitable for CSH. To evaluate relative importance in multiple causation, web of causation model with directed acyclic graph (Fig. 1) is more suitable. Development of CSH starts from the separation of the dural border cell (DBC) layer, which can occur either by trauma or low intracranial pressure. Severe trauma cannot produce a CSH even in a patient with coagulopathy, when the subdural space is not enough. Trauma cannot be the causality of $\mathrm{CSH}$ in this situation. Furthermore, CSH may occur without trauma. Causation implies that there is a true mechanism that leads from exposure to disease. Trauma or bleeding tendency is frequently associated with $\mathrm{CSH}$ and they may precipitate development of $\mathrm{CSH}$, however, it cannot lead $\mathrm{CSH}$, if there is no prerequisite. The key determinant for development of $\mathrm{CSH}$ is a sufficient subdural space, in other words, cerebral atrophy. The most common and universal cause of cerebral atrophy is the aging. If we classify a disease according to the key determinant, cerebral atrophy is responsible for the CSH instead of trauma.

Trauma was so frequently observed that CSH might be a traumatic lesion. The majority of CSHs are suspected by an undiagnosed trivial head injury. This assumption is hard to ex- 


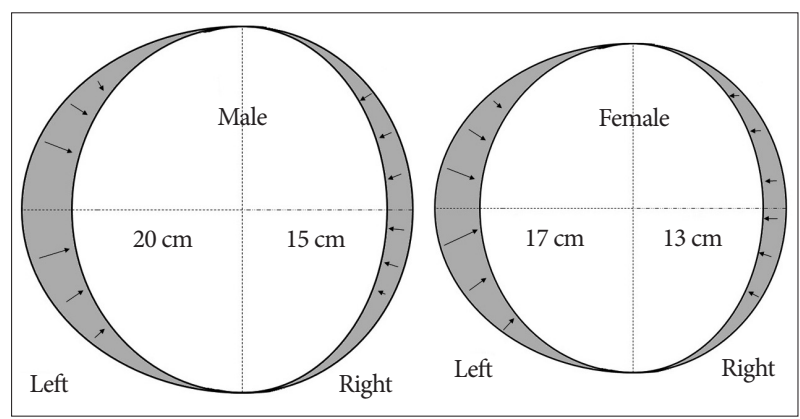

Fig. 2. Schematic explanation for the difference in the incidence of chronic subdural hematoma. Anatomical difference of the cranium may influence the left and male prevalence of chronic subdural hematoma. The length and degree of atrophy in this figure are not actual data.

plain why CSH is rare in the young with severe head injury, while the majority of CSH occur in the old even without trauma ${ }^{33)}$. In patients without trauma history, we presumed that they forgot the trauma, since the CSH is common in the aged and alcoholics. However, there are numerous cases of CSHs without trau$\mathrm{ma}^{3,7,8,10,11,15,24,28,30,39,40,42,47-49,59,62)}$, which made trauma as an associated factor instead of the cause.

Bleeding tendency clearly has a significant association with an increased risk of $\mathrm{CSH}^{14)}$. Because of the continuing rise of life expectancy and the increasing use of anticoagulants, the incidence of CSH is expected to rise $e^{4,5,14,20,35)}$. Anticoagulant and antiplatelet therapy became an important risk factor for development of CSH. However, bleeding tendency cannot lead CSH by itself.

Although about two-thirds (57-78.7\%) of CSHs were in persons older than 65 years ${ }^{5,53)}$, CSH does not occur in all aged person. Since aging and cerebral atrophy are universal, atrophy alone is not enough to explain the causality of CSH. The author suspect the cranial size and morphology as an important predisposing factor. Cerebral atrophy produce negative pressure within the cranium. This negative pressure is constant on each side of the cranium, according to Boyle's law, which the pressure of gas tried to hold at a constant temperature change by inverse with the volume of the gas. As the degree of atrophy is constant, the decreased length of brain diameter on the large hemisphere is longer than on the small hemisphere (Fig. 2). So, the distance from the skull to the cerebral cortex in the shrunken hemisphere is longer on the side of large hemisphere. The bridging vein is more stretched on the large hemisphere, so it may be tore by a trivial injury. If the distance exceeds the length of the arachnoid trabeculae, separation of the DBC layer will occur at the large hemisphere, which will create so-called the subdural space. For example, overall $10 \%$ reduction result $2 \mathrm{~cm}$ in the left, 1.5 $\mathrm{cm}$ in the right in the male cranium. While in the female cranium, $9 \%$ reduction (the degree of atrophy is less severe than male) of shorter diameter result about $1.5 \mathrm{~cm}$ in the left side. This anatomical difference of the cranium influences the left and male prevalence of $\mathrm{CSH}$. Actual separation of the DBC layer will depends on the force pulling the arachnoid trabeculae, which is the sum of the cranial morphology and the degree of cerebral atrophy.

\section{CONCLUSION}

The origin of a CSH is multiple. It can be developed spontaneously, or changed from a subdural hygroma or an acute subdural hematoma. A more important prerequisite is sufficient potential subdural space that is aging, degeneration of the brain. $\mathrm{CSH}$ was a stroke in 17 th century ${ }^{13)}$, an inflammation in 19th century, and it became a traumatic lesion in 20th century ${ }^{38)}$. Virchow recognized that hematoma durae matris sometimes was traumatic, but he believed that this lesion was most often caused by chronic inflammation (pachymeningitis chronica hemorrhagica) of the dura ${ }^{13,54)}$. Modifying Virchow's description, $\mathrm{CSH}$ is sometimes traumatic, but most often caused by degeneration of the brain. Now, it would be reasonable that in the aged persons, degeneration of brain might play the most important role in development of $\mathrm{CSH}$.

\section{References}

1. Adhiyaman V, Asghar M, Ganeshram KN, Bhowmick BK : Chronic subdural haematoma in the elderly. Postgrad Med J 78 : 71-75, 2002

2. Amorim JA, Remígio DS, Damázio Filho O, de Barros MA, Carvalho VN, Valença MM : Intracranial subdural hematoma post-spinal anesthesia : report of two cases and review of 33 cases in the literature. Rev Bras Anestesiol 60 : 620-629, 344-349, 2010

3. Arpino L, Gravina M, Basile D, Franco A : Spontaneous chronic subdural hematoma in a young adult. J Neurosurg Sci 53 : 55-57, 2009

4. Aspegren OP, Åstrand R, Lundgren MI, Romner B : Anticoagulation therapy a risk factor for the development of chronic subdural hematoma. Clin Neurol Neurosurg 115 : 981-984, 2013

5. Balser D, Farooq S, Mehmood T, Reyes M, Samadani U : Actual and projected incidence rates for chronic subdural hematomas in United States Veterans Administration and civilian populations. J Neurosurg 20 : $1-7,2015$

6. Barrios L, Clément R, Visseaux G, Bord E, Le Gall F, Rodat O : A case of atypical chronic subdural hematoma : a spontaneous rupture of dural lymphoma nodule. J Forensic Leg Med 22 : 145-147, 2014

7. Beck J, Gralla J, Fung C, Ulrich CT, Schucht P, Fichtner J, et al. : Spinal cerebrospinal fluid leak as the cause of chronic subdural hematomas in nongeriatric patients. J Neurosurg 121 : 1380-1387, 2014

8. Berhouma M, Houissa S, Jemel H, Khaldi M : Spontaneous chronic subdural hematoma of the posterior fossa. J Neuroradiol 34 : 213-215, 2007

9. Borger V, Vatter H, Oszvald Á, Marquardt G, Seifert V, Güresir E : Chronic subdural haematoma in elderly patients : a retrospective analysis of 322 patients between the ages of 65-94 years. Acta Neurochir (Wien) $154:$ 1549-1554, 2012

10. Bosche B, Molcanyi M, Noll T, Kochanek M, Kraus B, Rieger B, et al. : Occurrence and recurrence of spontaneous chronic subdural haematoma is associated with a factor XIII deficiency. Clin Neurol Neurosurg $115: 13-18,2013$

11. Bosma JJ, Miles JB, Shaw MD : Spontaneous chronic and subacute subdural haematoma in young adults. Acta Neurochir (Wien) 142 : 13071310, 2000

12. Cheng SY, Chang CK, Chen SJ, Lin JF, Tsai CC : Chronic subdural hematoma in elderly taiwan patients : a retrospective analysis of 342 surgical cases. Int J Geront 8 : 37-41, 2014 
13. D’Errico AP, German WJ : Chronic Subdural Hematoma. Yale J Biol Med $3: 11-20,1930$

14. De Bonis P, Trevisi G, de Waure C, Sferrazza A, Volpe M, Pompucci A, et al. : Antiplatelet/anticoagulant agents and chronic subdural hematoma in the elderly. PLoS One 8 : e68732, 2013

15. De Carvalho D, Almenawer S, Lozej M, Noble H, Murty NK : Spontaneous chronic subdural hematoma in a 22-year-old healthy woman. World Neurosurg 80 : 654.e9-e11, 2013

16. Edmondson L, Upshaw JE, Tuuri RE : A 14-year-old male with a 10week history of headaches. Pediatr Ann 43 : 220, 222-223, 2014

17. Eljebbouri B, Okacha N, Boucetta M : Chronic subdural hematoma infected by Campylobacter fetus. Surg Infect (Larchmt) 14: 563-564, 2013

18. Ferrante E, Arpino I, Citterio A, Wetzl R, Savino A : Epidural blood patch in Trendelenburg position pre-medicated with acetazolamide to treat spontaneous intracranial hypotension. Eur J Neurol 17 : 715-719, 2010

19. Fogelholm R, Heiskanen O, Waltimo O : Chronic subdural hematoma in adults. Influence of patient's age on symptoms, signs, and thickness of hematoma. J Neurosurg 42 : 43-46, 1975

20. Forster MT, Mathé AK, Senft C, Scharrer I, Seifert V, Gerlach R : The influence of preoperative anticoagulation on outcome and quality of life after surgical treatment of chronic subdural hematoma. J Clin Neurosci $17: 975-979,2010$

21. Gabaeff SC : Investigating the possibility and probability of perinatal subdural hematoma progressing to chronic subdural hematoma, with and without complications, in neonates, and its potential relationship to the misdiagnosis of abusive head trauma. Leg Med (Tokyo) 15 : 177192, 2013

22. Goto T, Ohshima S, Miura K, Shibuya T, Sato W, Dohmen T, et al. : A chronic subdural hematoma in a patient receiving combination therapy with pegylated interferon alfa- $2 \mathrm{~b}$ and ribavirin for chronic hepatitis $\mathrm{C}$. Intern Med 52 : 2057-2060, 2013

23. Hagihara N, Abe T, Kojima K, Watanabe M, Tabuchi K : Coexistence of cranial and spinal subdural hematomas : case report. Neurol Med Chir (Tokyo) 50 : 333-335, 2010

24. Hong JC, Kim MS, Chang CH, Kim SH : Arachnoid cyst with spontaneous intracystic hemorrhage and chronic subdural hematoma. J Korean Neurosurg Soc 43 : 54-56, 2008

25. Inamasu J, Watabe T, Ganaha T, Yamada Y, Nakae S, Ohmi T, et al. : Clinical characteristics and risk factors of chronic subdural haematoma associated with clipping of unruptured cerebral aneurysms. J Clin Neurosci 20 : 1095-1098, 2013

26. Kawano H, Yamamoto D, Uchihashi Y, Wakahashi K, Kawano Y, Sada A, et al. : Severe inhibitor-negative acquired factor XIII/13 deficiency with aggressive subdural haemorrhage. Blood Coagul Fibrinolysis 24 : 638-641, 2013

27. Kertmen H, Gürer B, Yilmaz ER, Sekerci Z : Chronic subdural hematoma associated with an arachnoid cyst in a juvenile taekwondo athlete : a case report and review of the literature. Pediatr Neurosurg 48 : 55-58, 2012

28. Kim BW, Jung YJ, Kim MS, Choi BY : Chronic subdural hematoma after spontaneous intracranial hypotension : a case treated with epidural blood patch on c1-2. J Korean Neurosurg Soc 50 : 274-276, 2011

29. Kuan-Yin T, Dueng-Yuan H, Hsin-I M : Subdural hematoma associated with skull and dural metastasis of gastric carcinoma : a case report. Turk Neurosurg 23 : 796-799, 2013

30. Kuramae T, Inamasu J, Nakagawa Y, Nakatsukasa M : Spontaneous intracranial hypotension presenting without orthostatic headache complicated by acute subdural hematoma after drainage for chronic subdural hematoma--case report. Neurol Med Chir (Tokyo) 51 : 518-521, 2011

31. Kwak YS, Hwang SK, Park SH, Park JY : Chronic subdural hematoma associated with the middle fossa arachnoid cyst : pathogenesis and re- view of its management. Childs Nerv Syst 29: 77-82, 2013

32. Ledić D, Girotto D, Pal S, Kolbah B : Risk factors for subdural bleeding in elderly population. Coll Antropol 38 : 1195-1198, 2014

33. Lee KS, Bae WK, Doh JW, Bae HG, Yun IG : Origin of chronic subdural haematoma and relation to traumatic subdural lesions. Brain Inj 12 : 901-910, 1998

34. Lee KS, Bae WK, Park YT, Yun IG : The pathogenesis and fate of traumatic subdural hygroma. Br J Neurosurg 8 : 551-558, 1994

35. Lindvall P, Koskinen LO : Anticoagulants and antiplatelet agents and the risk of development and recurrence of chronic subdural haematomas. J Clin Neurosci 16: 1287-1290, 2009

36. Lohani S, Robertson RL, Proctor MR : Ruptured temporal lobe arachnoid cyst presenting with severe back pain. J Neurosurg Pediatr 12 : $281-283,2013$

37. Luongo M, Pizzuti M, Godano U : Bilateral chronic subdural non-traumatic hematoma associated with von Willebrand's type I disease : a case report. Acta Neurochir (Wien) $154:$ 1087-1088, 2012

38. Markwalder TM: Chronic subdural hematomas : a review. J Neurosurg $54: 637-645,1981$

39. Missori P, Domenicucci M, Sassun TE, Tarantino R, Peschillo S : Alterations in the intracranial venous sinuses in spontaneous nontraumatic chronic subdural hematomas. J Clin Neurosci $20: 389-393,2013$

40. Mori K, Maeda M : Surgical treatment of chronic subdural hematoma in 500 consecutive cases : clinical characteristics, surgical outcome, complications, and recurrence rate. Neurol Med Chir (Tokyo) 41 : 371381, 2001

41. Ohno T, Iihara K, Takahashi JC, Nakajima N, Satow T, Hishikawa T, et al. : Incidence and risk factors of chronic subdural hematoma after aneurysmal clipping. World Neurosurg 80 : 534-537, 2013

42. Park HR, Lee KS, Shim JJ, Yoon SM, Bae HG, Doh JW : Multiple densities of the chronic subdural hematoma in CT scans. J Korean Neurosurg Soc $54: 38-41,2013$

43. Pirayesh Islamian A, Polemikos M, Krauss JK : Chronic subdural haematoma secondary to headbanging. Lancet $384: 102,2014$

44. Prasad BC, Chandra VV, Varaprasad G : Dural metastases in chronic myeloid leukemia presenting as subdural hematoma. Turk Neurosurg $22: 777-778,2012$

45. Reichman J, Singer S, Navi B, Reiner A, Panageas K, Gutin PH, et al. : Subdural hematoma in patients with cancer. Neurosurgery $71: 74-79,2012$

46. Sakai N, Akamine S, Tokuyama T, Sugiyama K, Kanayama N, Namba H : Chronic subdural hematoma in a patient with congenital afibrinogenemia successfully treated with fibrinogen replacement. Neurol Med Chir (Tokyo) $51: 780-783,2011$

47. Schievink WI : Stroke and death due to spontaneous intracranial hypotension. Neurocrit Care 18: 248-251, 2013

48. Schievink WI, Maya MM, Moser FG, Tourje J : Spectrum of subdural fluid collections in spontaneous intracranial hypotension. J Neurosurg $103: 608-613,2005$

49. Schievink WI, Maya MM, Pikul BK, Louy C : Spontaneous spinal cerebrospinal fluid leaks as the cause of subdural hematomas in elderly patients on anticoagulation. J Neurosurg 112: 295-299, 2010

50. Seçkin H, Kazanci A, Yigitkanli K, Simsek S, Kars HZ : Chronic subdural hematoma in patients with idiopathic thrombocytopenic purpura : a case report and review of the literature. Surg Neurol 66 : 411-414; discussion 414, 2006

51. Senturk S, Guzel E, Bayrak AH, Bukte Y, Guzel A : Factor X deficiency presenting with bilateral chronic subdural hematoma. Pediatr Neurosurg $46: 54-57,2010$

52. Sim YW, Min KS, Lee MS, Kim YG, Kim DH : Recent changes in risk factors of chronic subdural hematoma. J Korean Neurosurg Soc 52 : 234-239, 2012

53. Sousa EB, Brandão LF, Tavares CB, Borges IB, Neto NG, Kessler IM : 
Epidemiological characteristics of 778 patients who underwent surgical drainage of chronic subdural hematomas in Brasilia, Brazil. BMC Surg $13: 5,2013$

54. Taarnhoj P : Chronic subdural hematoma; historical review and analysis of 60 cases. Cleve Clin Q 22 : 150-156, 1955

55. Takayasu T, Harada K, Nishimura S, Onda J, Nishi T, Takagaki H : Chronic subdural hematoma associated with arachnoid cyst. Two case histories with pathological observations. Neurol Med Chir (Tokyo) 52 : 113-117, 2012

56. Tan VE, Liew D : A case of chronic subdural hematoma following lumbar drainage for the management of iatrogenic cerebrospinal fluid rhinorrhea : pitfalls and lessons. Ear Nose Throat J 92 : 513-515, 2013

57. Tanaka Y, Ohno K : Chronic subdural hematoma - an up-to-date concept. J Med Dent Sci 60 : 55-61, 2013

58. Tekin T, Colak A, Kutlay M, Demircan MN : Chronic subdural hematoma after endoscopic third ventriculostomy : a case report and literature review. Turk Neurosurg 22 : 119-122, 2012

59. Thirumal Y, Alugolu R : Spontaneous chronic subdural hematoma following Plasmodium vivax malaria : a rare association. J Vector Borne
Dis 51 : 73-74, 2014

60. Tseng JH, Tseng MY, Liu AJ, Lin WH, Hu HY, Hsiao SH : Risk factors for chronic subdural hematoma after a minor head injury in the elderly : a population-based study. Biomed Res Int $2014: 218646,2014$

61. Vuk A, Stancić V, Rincić G, Ledinsky M, Grbac L, Stancić N : Nontraumatic bilateral subdural hematoma caused by antiaggregation therapy : case report and review of the literature. Acta Clin Croat 49: 163-168, 2010

62. Wang HS, Kim SW, Kim SH : Spontaneous chronic subdural hematoma in an adolescent girl. J Korean Neurosurg Soc 53 : 201-203, 2013

63. Yang AI, Balser DS, Mikheev A, Offen S, Huang JH, Babb J, et al. : Cerebral atrophy is associated with development of chronic subdural haematoma. Brain Inj 26 : 1731-1736, 2012

64. Yoshida H, Takai K, Taniguchi M : Leakage detection on CT myelography for targeted epidural blood patch in spontaneous cerebrospinal fluid leaks : calcified or ossified spinal lesions ventral to the thecal sac. J Neurosurg Spine $21: 432-441,2014$

65. Zeng T, Shi SS, Lin YF : Chronic subdural hematoma associated with sylvian arachnoid cyst in juvenile athletes : report of two cases and literature review. Chin J Traumatol 14 : 174-177, 2011 